\title{
Spectral signature of suspended fine particulate material on light absorption properties of CDOM
}

Massicotte, Philippe; Stedmon, Colin; Markager, Stiig

Published in:

Marine Chemistry

Link to article, DOI:

10.1016/j.marchem.2017.07.005

Publication date:

2017

Document Version

Peer reviewed version

Link back to DTU Orbit

Citation (APA):

Massicotte, P., Stedmon, C., \& Markager, S. (2017). Spectral signature of suspended fine particulate material on light absorption properties of CDOM. Marine Chemistry, 196, 98-106.

https://doi.org/10.1016/j.marchem.2017.07.005

\section{General rights}

Copyright and moral rights for the publications made accessible in the public portal are retained by the authors and/or other copyright owners and it is a condition of accessing publications that users recognise and abide by the legal requirements associated with these rights.

- Users may download and print one copy of any publication from the public portal for the purpose of private study or research.

- You may not further distribute the material or use it for any profit-making activity or commercial gain

- You may freely distribute the URL identifying the publication in the public portal

If you believe that this document breaches copyright please contact us providing details, and we will remove access to the work immediately and investigate your claim. 
Spectral signature of suspended fine particulate material on light absorption properties of CDOM

Philippe Massicotte $^{*, 1}$, Coilin stedmon ${ }^{2}$, and Stiig Markager ${ }^{1}$

1 - Aarhus University, Department of Bioscience, Frederiksborgvej 399, DK-4000

Roskilde, Denmark, philippe.massicotte@ takuvik.ulaval.ca

2 - Technical University of Denmark, National Institute for Aquatic Resources, Section for Marine Ecology and Oceanography, Kavalergården 6, 2920 Charlottenlund, Denmark

* Corresponding author. Present address: Takuvik Joint International Laboratory (UMI 3376) Université Laval (Canada) \& Centre National de la Recherche Scientifique (France) Québec-Océan / Pavillon Alexandre-Vachon 1045, Ave de la Médecine, local 2064 Université Laval Québec (Québec)

Keywords: CDOM, light absorption, filtration, colloids, DOM, primary production Running head: Influence of colloids on CDOM 


\begin{abstract}
Fine submicron organic particles can represent an important fraction of the dissolved organic matter (DOM) pool in aquatic ecosystems and their optical properties differ from those normally considered dissolved $(<0.2 \mu \mathrm{m})$, which means that the choice of filter type/pore size can influence the light absorption characteristics. In this study, a total of 867 paired CDOM absorption spectra $(n=1734)$ from different ecosystems (lakes, streams, sewages and estuaries) were measured on $0.2 \mu \mathrm{m}$ and $\mathrm{GF} / \mathrm{F}$ (nominal pore size $0.7 \mu \mathrm{m}$ ) filters. The aims was to evaluate how fine organic particles influence the spectral signature of the DOM pool and to quantify the effects of choice of filter type. In aquatic ecosystems influenced by terrestrial DOM (rivers and lakes), the dissolved fraction (here defined as $<0.2 \mu \mathrm{m})$ overwhelmed the fine particulate signal $(0.2-0.7 \mu \mathrm{m})$ which did not contribute significantly to the absorption signal. In contrast, freshly-produced fine particles released by phytoplankton significantly increased measured CDOM absorption in productive environments with low terrestrial background. Our results demonstrate that the choice of filter pore size can have a significant impact on the outcome of spectral metrics often used to characterise CDOM such as the spectral slope (S) or the slope ratio (SR). Hence, this may complicate the combining CDOM absorption measurements from different studies where different pore sizes were used as fine particulate material may significantly influence the spectral signature, particularly in situations where phytoplankton is the dominating source of DOM.
\end{abstract}




\section{Introduction}

Dissolved organic matter (DOM) represent a considerable organic carbon reservoir in both marine (Benner2002) and freshwater ecosystems (Cole2007) and influences their functioning in numerous ways. The optical and chemical properties of DOM determine underwater light characteristics (Kirk1994), the composition of aquatic microbial communities (Foreman2003; Kritzberg2006), the carbon cycling on local to global scales (Cole2007) and the availability and transport of nitrogen (Markager2011; Jorgensen2014).

Phytoplankton and other primary producers are important sources of DOM in both marine and freshwater ecosystems (Baines1991; Demarty2009; Lapierre2009). DOM originating from phytoplankton includes a broad range of organic molecules of different sizes (Sundh1992; Mannino2002). Additionally, the gradual degradation of sinking particles adds to the size continuum maintaining a broad spectrum of organic matter from larger sinking aggregates, to fine suspended particulate material to dissolved material. The boundaries between dissolved and particulate are somewhat arbitrary and often dependent on the focus of the study. In general organic particles less than $1 \mu \mathrm{m}$ have such slow settling rates that their distribution is mainly controlled by water advection. Spanning the boundary between particulate and dissolved is the colloidal fraction which is operationally considered as solutes in the range of 1-400 $\mathrm{kDa}$, which approximately corresponds to 0.001-0.4 $\mu \mathrm{m}$ (Morel1987). Earlier studies have linked planktonic primary production with colloids that can contribute significantly to light absorption (Boehme2006; Floge2007). Colloidal material is known to influence light scattering in the ocean (Stramski2005; Coble2007) which is likely influencing the spectral signature of the chromophoric fraction of the DOM pool (CDOM). In many studies, the operational definition of DOM is variable and $0.2 \mu \mathrm{m}, 0.4 \mu \mathrm{m}, 0.7 \mu \mathrm{m}(\mathrm{GF} / \mathrm{F})$ or even $1.2 \mu \mathrm{m}(\mathrm{GF} / \mathrm{C})$ filters are used to separate the dissolved and the particulate fractions (Nimptsch 2014). The choice of the filter pore sizes is likely to influence the relative contribution of the fine particulate fraction to the spectral signature of the CDOM pool. This can complicate our interpretation of changes seen the spectral signature of CDOM across aquatic 
ecosystems, in particular on derived metrics like spectral slope values across specific wavelength ranges.

As much effort is currently underway to use optical measurements to understand the roles of DOM on the functioning of aquatic ecosystems at global scales (Massicotte2017), it is important to document how fine (suspended) particulate organic matter influences CDOMs spectral properties and in which environments this influence is greatest. The aim of this study was to evaluate the influence of colloidal DOM on the absorption properties of CDOM. A total of 867 paired absorbance spectra of CDOM $(n=1734)$ were measured from different ecosystems (lakes, streams, sewages and estuaries) as well as from a mesocosm experiment where the DOM pool was dominated by fresh DOM from phytoplankton. Samples were filtered on both polycarbonate $0.2 \mu \mathrm{m}$ pore filters and precombusted GF/F matrix filters. Using this comprehensive dataset, we quantified how fine particulate organic material $(0.2-0.7 \mu \mathrm{m})$ influences the spectral signature of CDOM and under which circumstances their effects were most pronounced.

\section{Material and methods}

\section{Sampling and data collection}

The data compiled for this analysis originates from two campaigns. The first set of absorbance spectra is from a sampling campaign in the Horsens estuary and its catchment on the east coast of the Jutland peninsula in Denmark between August 2001 and September 2002 (Stedmon2006; Markager2011). Fourteen stations were sampled approximately weekly for a year. Five stations were located in the estuary, nine in streams feeding the estuary, two in surrounding lakes and one in the outflow of Horsens wastewater treatment plant. The land use in the catchment is dominated by agriculture (75\%) and the estuary is eutrophic with total nitrogen ranging between 40 and $60 \mu \mathrm{mol}$ and chlorophyll concentrations in the productive season at about $10 \mu \mathrm{g} \mathrm{Chl} 1^{-1}$.

The second set of absorbance spectra is from a marine mesocosm experiment carried out in Raunefjord close to Bergen in Norway in August 2002. Briefly, five bags of $11 \mathrm{~m}^{3}$ were deployed hanging from a raft about 200 meters from the land (Stedmon2005a; 
Conan2007). The bags were filled with seawater from the fjord and renewed with water from the fjord at a rate of $10 \%$ of the volume per day. Artificial blooms were produced by adding nutrients daily for a week at different $\mathrm{N}: \mathrm{P}$ ratios with and without silica (Supplementary Fig. 1). Then, the nutrient addition was stopped and the phytoplankton community went into a stationary phase. Thus, in this dataset DOM originates from both the estuary and freshly produced DOM from the plankton community.

\section{Absorbance measurements}

Absorbance was measured on filtrates of both $0.2 \mu \mathrm{m}$ polycarbonate membranes (Minisart syringe filter) and pre-combusted $25 \mathrm{~mm} 0.7 \mu \mathrm{m} \mathrm{GF} / \mathrm{F}$ filters (Advantec) using a Millipore stainless steel syringe filter housing. All samples were stored cold $\left(4^{\circ} \mathrm{C}\right)$ and in the dark until measurement. The Horsens samples were measured approximately one week after sampling while the mesocosm samples were measured on the sampling day. For the Horsens dataset, a total of 618 paired absorbance spectra were measured $(n=$ 1236) whereas for the mesocosm dataset a total of 249 paired spectra were measured ( $n=$ 498). Spectra were measured between $240-700 \mathrm{~nm}$ at $0.5 \mathrm{~nm}$ increments on a Shimadzu UV-2401PC spectrophotometer with Milli-Q water as reference. The Napierian absorption coefficient, $a_{\mathrm{CDOM}}(\lambda)\left(\mathrm{m}^{-1}\right)$ was calculated by multiplying absorbance at wavelength $\lambda(\mathrm{nm})$ by 2.303 and then dividing with the path length of the cuvette in meter (Stedmon and Markager, 2001). The cuvette size used for absorbance measurements varied depending on the sample location. For mesocosm and Horsens fjords samples a 10 $\mathrm{cm}$ quartz cuvette was used. Freshwater samples from the Horsens catchment were measured in either 5 or $1 \mathrm{~cm}$ cuvette depending on CDOM concentration. According to their origin, each paired absorbance spectra were assigned to a specific ecosystem as follows: estuary $(n=471)$, lake $(n=62)$, sewage $(n=33)$, stream $(n=301)$. For the remainder of the text, the terms $0.2 \mu \mathrm{m}$ and $0.7 \mu \mathrm{m}$ filtrates refer to filtrates processed through $0.2 \mu \mathrm{m}$ polycarbonate and pre-combusted GF/F filters respectively. It should be noted that there are indications that pre-combustion might reduce the effective pore size to $0.3 \mu \mathrm{m}$ for $\mathrm{GF} / \mathrm{F}$ (Nayar2003). The filters used in the study were of the same type and treated in exactly the same manner across all sampling campaigns. However, we have chosen to use the often-assumed nominal pore size of $0.7 \mu \mathrm{m}$. The fine particulate 
fraction studied here is therefore defined as particles between 0.2 and $0.7 \mu \mathrm{m}$, and falls within the ranges expected for colloids (Boehme2006; Guo2006; Floge2007).

\section{Spectral characteristics of CDOM}

Absorption spectra were modeled accordingly to equation 1 (Jerlov1968; Bricaud1981; Stedmon2001):

$$
a_{\mathrm{CDOM}}(\lambda)=a_{\mathrm{CDOM}}(\lambda 0) e^{-S(\lambda-\lambda 0)}+K
$$

where $a_{\mathrm{CDOM}}$ is the absorption coefficient $\left(\mathrm{m}^{-1}\right), \lambda$ is the wavelength $(\mathrm{nm}), \lambda 0$ is a reference wavelength $(\mathrm{nm}), K$ is a background constant $\left(\mathrm{m}^{-1}\right)$ accounting for scatter produced in the cuvette by small particles or bubbles and $\mathrm{S}$ is the spectral slope parameter $\left(\mathrm{nm}^{-1}\right)$ that describes the approximate exponential decrease in absorption with increasing wavelength. Higher slopes indicate a more rapid decrease in absorption with increasing wavelength. For the remainder of the text, $S_{300-600,} S_{275-295}$ and $S_{350-400}$ denote the spectral slopes calculated between the specified wavelengths. The slope ratio (SR) is the

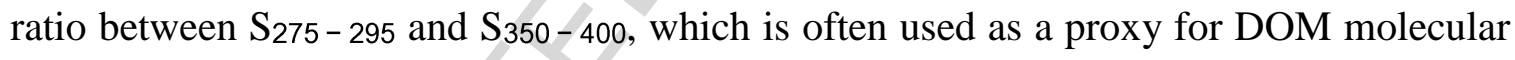
weight (Helms2008). The absorption coefficient at $240 \mathrm{~nm}$ varied between 6 and 205 $\mathrm{m}^{-1}$. Hence, for some analyses each spectrum was normalized to its maximum value to highlight the differences in the spectral shape between measurements.

\section{Statistical analysis}

Orthogonal regressions (or type II regressions) were used to explore the relationship between absorption measured on the two filters types using the lmodel2() function from the lmodel2 R package (Legendre2014). Unlike a simple linear regression, an orthogonal regression assumes that both the response and the predictor contain measurement errors. The CDOM characteristics were calculated using the cdom $\mathrm{R}$ package (Massicotte2016MC). All statistical analyses were performed in R version 3.3.3. 


\section{Results}

\section{Effect of filter size on absorption spectra}

Average CDOM absorption spectra for each of the two filter types are shown in Fig. 1 for estuary, lake, sewage and stream ecosystems, respectively. The absorption spectra showed the usual exponential decrease with increasing wavelengths but with a shoulder at approximately $280 \mathrm{~nm}$. This feature was most pronounced in the estuary and wastewater samples. At $240 \mathrm{~nm}$, the averaged absorption coefficients ranged between approximately $10 \mathrm{~m}^{-1}$ for samples from the estuaries to $70 \mathrm{~m}^{-1}$ for spectra measured in streams and lakes (Fig. 1). Due to the large variability over the spectrum and high values for freshwater samples, differences in absorption between spectra measured on $0.2 \mu \mathrm{m}$ and $0.7 \mu \mathrm{m}$ filtrates are at first difficult to distinguish, although the expected lower values due to less material in the $0.2 \mu \mathrm{m}$ filtrate are visible between $240-270 \mathrm{~nm}$.

Normalized spectra from paired samples with the lowest and the highest differences (i.e. the differences in integrated absorption between 240-700 nm) are presented in Fig. 2. The spectra with the highest differences in the four ecosystems (left column) revealed a similar systematic spectral pattern. Higher absorption was observed in the $0.7 \mu \mathrm{m}$ filtrate at $240 \mathrm{~nm}$ and the differences decreased with increasing wavelengths. The greatest differences between filtrates were seen in the estuary and stream spectra. In contrast, the spectra with the lowest differences (right column) showed near identical values between 240 and $500 \mathrm{~nm}$. Thus, the effect of filter pore size varied from none to substantial greater absorption in the $0.7 \mu \mathrm{m}$ filtrates.

At each wavelength, we calculated the mean difference in absorption measurements between the two filtrates (Fig. 3). In all ecosystems, the mean across all samples measured on $0.7 \mu \mathrm{m}$ filtrates was higher than that measured on $0.2 \mu \mathrm{m}$ filtrates, across all wavelengths, as revealed by the positive mean difference (Fig. 3, Supplementary Fig. 2). Analysis of variance (ANOVA) revealed that these differences were not significant at all wavelengths in lake or sewage ecosystems $(p>0.05)$. In the streams, differences were significant only at wavelengths greater than $433 \mathrm{~nm}$. In the two estuaries (Horsens and the mesocosms), significant differences were observed between 258 and $500 \mathrm{~nm}$. Another 
observation is that standard deviation (shaded areas in Fig. 3) decreased with increasing wavelength except for lake samples. Thus, the absorption by fine particulates is more variable in lakes at longer wavelength than in the other environments.

Despite the observation that the mean difference was not significantly different at many wavelengths, the effect of filter type could still be significant under some circumstances. The effects of filter pore size were therefore further analyzed with orthogonal regressions computed between absorption coefficients measured from both filtrates type at all wavelengths (Fig. 4). The analysis revealed two contrasting patterns between ecosystems. For the estuarine, lacustrine and wastewater samples, $\mathrm{R}^{2}$-values remained close to 1 below $325 \mathrm{~nm}$ and rapidly decreased to reach approximately 0.25 at $500 \mathrm{~nm}$ (Fig. 4A). For the stream ecosystem, $\mathrm{R}^{2}$ was above 0.75 along the complete spectral range. However, it was common for all four ecosystem types that both the slopes and the $\mathrm{R}^{2}$ values decreased with increasing wavelengths, showing a gradually higher relative effect of fine particles causing an increasing discrepancy between the absorption measured on 0.2 and $0.7 \mu \mathrm{m}$ filtrates (Fig. 4). This indicates that the significant contribution from these particles was most pronounced when the absorption of CDOM was low (at longer wavelengths).

\section{Primary production and colloidal scattering}

The mesocosm experiment provided an opportunity to quantify the effect of fine particulate organic matter produced by the marine microbial community on the spectral signature of CDOM as primary production was increasing over the time of the experiment (Fig. 5). When the mesocosm bags were filled at day zero, the CDOM pool was equivalent to the pool in the estuary, which is assumed to be dominated by terrestrial DOM as the system is relatively oligotrophic. The nutrient addition created a phytoplankton bloom where averaged primary production rates increased from 0.39 mmol $\mathrm{C} \mathrm{m}^{-2} \mathrm{~h}^{-1}$ to $15.4 \mathrm{mmol} \mathrm{C} \mathrm{m} \mathrm{m}^{-2} \mathrm{~h}^{-1}$ during the first 10 days before reaching a plateau for the rest of the experiment (Fig. 5A, Supplementary Fig. 1A). This production caused an equivalent increase in chlorophyll a concentration (Fig. 5B, Supplementary Fig. 1B) and dissolved organic carbon (DOC, Fig 5C) indicating an accumulation of 
freshly produced DOM of marine origin. During the experiment, average DOC concentration increased linearly from $128 \mu \mathrm{mol} \mathrm{L}^{-1}$ to $197 \mu \mathrm{mol} \mathrm{L}^{-1}$ (Fig. 5C, $\mathrm{R}^{2}=0.95$ ). $S_{300-600}$ was found to decrease rapidly during the first part of mesocosm experiment (Supplementary Fig. 3), which indicates an increase in molecular weight since it is known to correlates negatively with DOM molecular weight (Stedmon2015b). Furthermore, the average difference between $S_{300}-600$ measured from each filtrate $\left(\Delta S_{300-}\right.$ 600) increased linearly from $0.0007 \mathrm{~nm}^{-1}$ to $0.0019 \mathrm{~nm}^{-1}$ at the end of the experiment (Fig. 5D, $\mathrm{R}^{2}=0.67$ ). This indicates that the apparent increase in CDOM molecular weight was due to the $0.7 \mu \mathrm{m}$ filtrate and hence most likely associated with the fine particulate fraction.

The background constant $\mathrm{K}$ (equation 1) is a proxy for scattering in the cuvette and caused by particles unless bubbles are introduced during filtration and handling of the samples (Stedmon2001). A significant difference between K calculated from both filtrates was found in the mesocosm dataset $\left(F_{(1,496)}=43.61, p<0.0001\right.$, Fig. 6A) whereas no significant differences were observed between any ecosystems in the Horsens dataset (Fig. 6B). The difference between the K parameter calculated on $0.7 \mu \mathrm{m}$ and 0.2 $\mu \mathrm{m}$ filtrates $(\Delta \mathrm{K})$ during the mesocosm experiment increased linearly from $0.010 \mathrm{~m}^{-1}$ to $0.036 \mathrm{~m}^{-1}\left(\mathrm{R}^{2}=0.69, \mathrm{p}<0.001\right.$, Fig. $\left.6 \mathrm{C}\right)$. This indicates that the scattering increased systematically over time, which further indicates the formation of fine particles associated with increased contribution of marine CDOM.

\section{Effects of colloids on spectral characteristics of CDOM}

Commonly calculated CDOM metrics, S-values and slope ratios (SR), derived from spectra measured on each filtrate are compared in Fig. 7 (see also Supplementary Table 1). Determination coefficients $\left(R^{2}\right)$ varied between 0 and 0.85 indicating that under certain circumstances, the effect of colloidal material and consequently the choice of filter pore size can have important consequences on the outcomes of the calculated 
metrics. For instance, metrics calculated at shorter wavelengths $\left(S_{275}-295\right)$ or using the large spectral range $\left(\mathrm{S}_{300}-600\right)$ were generally less sensitive to the effect of colloidal material as indicated by high $\mathrm{R}^{2}$ values. On the other hand, metrics calculated at longer wavelengths $\left(\mathrm{S}_{350-400}\right.$, and hereby also $\left.\mathrm{SR}\right)$ showed greater discrepancy. A general observation is that most of the regression lines are below the 1:1 line indicating that on average $S$ calculated from $0.2 \mu \mathrm{m}$ filtrates were higher than those calculated on $0.7 \mu \mathrm{m}$ filtrates (Fig. 7, Supplementary Fig. 4). In most cases, p-values associated to parameter estimates were below 0.05 , indicating that both slope and intercept were significantly different from zero (Supplementary Table 1).

\section{Discussion}

Using a total of 1734 absorption spectra (867 paired spectra) from a range of aquatic ecosystems, our results show that the influence of fine particulate material on the spectral signature of CDOM varies according to the source, the pore size of the filter and the spectral region where measurements are compared. In productive aquatic environments with a relatively stable or low terrestrial signal (e.g. estuaries in productive season), fine particulates were found to influence absorption measurements (Fig. 5, Fig. 6) to a point where it has the potential to hinder cross-studies comparisons (Fig. 7, Supplementary Fig. 4). The results from the mesocosm experiments further showed the marine microbial foodweb is a potential source of higher molecular weight material.

\section{Influences of DOM sources on absorption properties of CDOM}

When differences were present, absorption measured on $0.7 \mu \mathrm{m}$ filtrates was found to be consistently higher than that measured on $0.2 \mu \mathrm{m}$ filtrates, as expected, since more material can pass through a larger pore size (Fig. 1, Fig. 2). Furthermore, the relative contribution of the $0.2-0.7 \mu \mathrm{m}$ fraction to the total absorption of CDOM was affected by the total absorption in the ecosystem. In freshwater ecosystems, the $0.2-0.7 \mu \mathrm{m}$ fraction can represent an important fraction of the DOM pool (Belzile2006; Guo2006). However, in the freshwater ecosystems in this study (rivers, lakes and wastewater) the CDOM signal was high enough that fine particulates did not sufficiently influence the spectral 
signature of the CDOM pool to create significant differences between absorption coefficients measured from 0.2 and $0.7 \mu \mathrm{m}$ filtrates (Fig. 3, Supplementary Fig. 2). This is in line with a previous study where fine particles were found to have an absorption coefficient of only $12 \%$ of the CDOM absorption at $440 \mathrm{~nm}$ (Watanabe2015). We hypothesize that the low influence of the fine particulate material on absorption measurements in freshwater ecosystems is because the dissolved fraction $(<0.2 \mu \mathrm{m})$ overwhelms the signal from fine particles $(0.2-0.7 \mu \mathrm{m})$ so it becomes difficult to detect (Fig. 3). In estuaries however, the mean difference in absorption measured from the two filtrates was found to be closer to the total absorption (Supplementary Fig. 2) suggesting that the contribution of terrestrial DOM $(<0.2 \mu \mathrm{m})$ to the total absorption signal was lower than in other ecosystems. This ultimately allowed colloidal DOM to significantly increase absorption at longer wavelengths and therefore influence the spectral signature of CDOM. Accordingly, we should expect the effect of colloids on absorption spectra to be even larger in open oceans.

\section{Influence of primary production on absorption properties of CDOM}

Protein-like material produced by phytoplankton is known to be an important source of colloidal DOM (Etheridge2004; Floge2007). The results from the mesocosm experiment presented here support this and indicate a clear accumulation of fine particulate material linked to DOC accumulation and increased chlorophyll a over time (Fig. 5A, 5B, Supplementary Fig. 1). Thus, given that $S_{300-600}$ is known to correlate negatively with

DOM molecular weight (Stedmon2015b), S300 - 600 was expected to decrease during the experiment as the proportion of the colloidal fraction gained in importance (Supplementary Fig. 3). An interesting finding is that the $S_{300-600}$ slopes calculated from $0.7 \mu \mathrm{m}$ filtrates decreased with a greater magnitude (Fig. 5D). This suggests that molecular weight increased more rapidly in the $0.7 \mu \mathrm{m}$ filtrates than in the $0.2 \mu \mathrm{m}$ filtrates, possibly showing that a large fraction of this colloidal material was retained on the $0.2 \mu \mathrm{m}$ pore filters. In agreement with findings from Floge2007 and Etheridge2004, the resulting rapid increase in DOC concentration suggests that fine particles were formed during the experiment, even after primary production and chlorophyll a had 
reached a plateau (Fig. 5C). Most likely, this increase in DOC concentrations and fine particles are due to a large production of DOC and concurrently increase in bacterial biomass when the phytoplankton community reaches a stationary phase. Previous experiments have shown a large production of highly biodegradable DOC when phytoplankton is nutrient limited and, hence, cannot utilize the carbon fixed in photosynthesis for growth (knudsen2016; Soendergaard2000).

Colloidal material can also be an important source of light scattering in aquatic ecosystems (Gallegos2005; Stramski2005; Coble2007). To account for this scattering effect by particles, Stedmon and Markager, 2001 introduced a background constant (K, $\mathrm{m}^{-1}$ ) in the original exponential formulation to model CDOM absorption spectra proposed by Bricaud1981 and Jerlov1968 (equation 1). We further verified that fine suspended particulate organic matter originating from primary producers induced higher light scattering in the measurement cuvette by comparing the $\mathrm{K}$ parameters estimated from $0.2 \mu \mathrm{m}$ and $0.7 \mu \mathrm{m}$ filtrates (Fig. 6). In the mesocosm experiment, we observed a significant difference in the value of the $\mathrm{K}$ parameter estimated from the two filtrates (Fig. 6A). In contrast, no difference was observed in the Horsens dataset where this fraction is thought to have less influence on absorption properties given the high terrestrial background signal from organic matter larger in size (Fig. 6B). Furthermore, we found that $\Delta \mathrm{K}$ (the difference between $\mathrm{K}_{0.7 \mu m}$ and $\mathrm{K}_{0.2 \mu m}$ ) increased over time during the mesocosm experiment (Fig. 6C). This indicates a contribution from fine particulate material accumulating in the mesocosms to both light absorption and scattering. These results are in line with findings from other studies which show that colloidal material (between 0.4 and $1 \mu \mathrm{m}$ ) is mainly derived from phytoplankton exudation, viral lysis and grazing processes (Wells1993) and that it covaries with phytoplankton biomass (Floge2007). Furthermore, Etheridge and Roesler, 2004 found out that $a_{\mathrm{CDOM}}(440)$ measured on 0.2-0.7 $\mu \mathrm{m}$ size-fractioned CDOM increased rapidly during an algal bloom in two Long Island embayments, implying that freshly produced protein-like DOM is an important driver influencing scattering and light absorption by DOM.

\section{Effect of filter size on CDOM metrics}


Absorption-based metrics such as the spectral slope (S) or the slope ratio (SR) are often the end-products derived from CDOM absorption spectra that are used to trace the dynamics of DOM across the aquatic ecosystem continuum (Stedmon2001; Mladenov2011; Lambert2015a). Although the mean difference in absorption was low compared to the raw signal in freshwater ecosystems (Fig. 3), our results show that fine particulate material can influence calculated CDOM metrics (Fig. 7, Supplementary Fig. 4). Linear regressions comparing metrics calculated from 0.2 and $0.7 \mu \mathrm{m}$ filtrates show that those calculated at higher wavelengths (e.g. $S_{350-400)}$ are more sensitive to this than those calculated at shorter wavelengths (e.g. $\mathrm{S}_{275}$-295). This indicates that the differences in absorption due to the colloidal fraction are more pronounced at higher wavelengths (Fig. 3, Fig. 4). A direct consequence of this is that fine particulate material significantly lowered S and increased SR in estuaries and streams (Supplementary Fig. 4A-C). Our results contrast with those from Nimptsch2014, who argued that the difference produced by the choice of filter type to the fluorescence signal was so small that meta-analyses of DOM composition based on studies with different pore size could be done. We speculate whether this perhaps reflects a mismatch between the colored and fluorescent fractions of DOM with fine particulates potentially influencing absorption more than fluorescence of organic matter, although further study is required to address this. However it is clear that combining absorption measurements of CDOM sampled with different pore filter sizes should be done with care, especially in productive ecosystems where fine particulate material can contribute significantly to the intensity and characteristics of absorption measured.

\section{Limitations}

In this study we assumed that the filter pore size was the main factor influencing the spectral signature of DOM. However, it is known that other factors such as volume of sample processed, pump pressure, amount of suspended sediment and the material of the filter can also be important (Horowitz1996). Additionally, there is evidence that at high concentrations DOM aggregation and pore clogging can decrease the effective pore size and cause the retention of increasing amounts of colloids (Morrison2001). We can 
therefore not exclude that these processes are responsible for the observed differences documented, especially in rivers and lakes where DOM high. However, in our study an identical consistent filtration approach was applied for all samples $(n=1734)$. The systematic nature of the patterns found in this study support that the observations represent actual differences in fine particulate material. It is also worth saying that this only used $0.2 \mu \mathrm{m}$ polycarbonate filters and that other types such as nylon and polyethersulfone are also commonly used. More study are therefore needed to examine the effect of filter material on the spectral signature of CDOM.

\section{Conclusions}

DOM is a central theme in ecology and more efforts are currently devoted to understand its roles on the functioning of aquatic ecosystems at global scales. In marine ecosystems, DOM dynamics it tightly linked with the primary production of phytoplankton communities. This study shows that fine suspended particles $(0.2-0.7 \mu \mathrm{m})$ can influence considerably the spectral signature of CDOM in marine environments with low terrestrial signal background. It is important to note that the results presented in this study are conservative since the effective pore size of the pre-combusted GF/F filters is likely to be smaller than $0.7 \mu \mathrm{m}$. Hence, the effects of fine particles on the spectral properties of CDOM are likely to be stronger. There is a growing need to combine optical datasets to formulate and test new hypotheses about DOM biogeochemical cycling. However, combining CDOM absorption measurements from disparate sources might not be a straightforward process because fine particulate material may significantly increase scattering and consequently the spectral signature of the CDOM pool.

\section{Acknowledgements}

P. Massicotte was supported by a postdoctoral fellowship from The Natural Sciences and Engineering Research Council of Canada (NSERC). C. Stedmon was funded by the Danish Council for Independent Research: Natural Sciences Grant (DFF-1323-00336). S. Markager was supported by the project Dissolved organic matter - from soil to sea funded by Aarhus University (Stiig Markager). Original sampling and measurement was supported by the European Union 5th framework DOMAINE project (EVK 3-CT-2000- 
00034, ELOISE No. 512/42). We acknowledge Ciarán Murray for helpful comments on the manuscript. 


\section{References}

Baines, S. B. and M. L. Pace (1991). "The production of dissolved organic matter by phytoplankton and its importance to bacteria: Patterns across marine and freshwater systems". In: Limnology and Oceanography 36.6, pp. 1078-1090.

Belzile, C. and L. Guo (2006). "Optical properties of low molecular weight and colloidal organic matter: Application of the ultrafiltration permeation model to DOM absorption and fluorescence". In: Marine Chemistry 98.2-4, pp. 183-196.

Benner, R. (2002). "Chemical composition and reactivity”. In: Biogeochemistry of marine dissolved organic matter. Ed. by D. A. Hansell and C. A. Carlson. San Diego, CA: Academic Press, pp. 59-90. Boehme, J. and M. Wells (2006). "Fluorescence variability of marine and terrestrial colloids: Examining size fractions of chromophoric dissolved organic matter in the Damariscotta River estuary”. In: Marine Chemistry 101.1-2, pp. 95-103.

Bricaud, A., A. Morel, and L. Prieur (1981). "Absorption by dissolved organic matter of the sea (yellow substance) in the UV and visible domains". In: Limnology and Oceanography 26.1, pp. 4353.

Coble, P. G. (2007). "Marine optical biogeochemistry: the chemistry of ocean color.” In: Chemical reviews 107.2 , pp. 402-418.

Cole, J. J., Y. T. Prairie, N. F. Caraco, W. H. McDowell, L. J. Tranvik, R. G. Striegl, C. M. Duarte, P. Kortelainen, J. A. Downing, J. J. Middelburg, and J. Melack (2007). "Plumbing the Global Carbon Cycle: Integrating Inland Waters into the Terrestrial Carbon Budget”. English. In: Ecosystems 10.1, pp. 172-185.

Conan, P., M. Søndergaard, T. Kragh, F. Thingstad, M. Pujo-Pay, P. J. 1. B. Williams, S. Markager, G. Cauwet, N. H. Borch, and D. Evans (2007). "Partitioning of organic production in marine plankton communities: The effects of inorganic nutrient ratios and community composition on new dissolved organic matter". In: Limnology and Oceanography 52.2, pp. 753-765.

Demarty, M. and Y. T. Prairie (2009). "In situ dissolved organic carbon (DOC) release by submerged macrophyte-epiphyte communities in southern Quebec lakes”. English. In: Canadian Journal of Fisheries and Aquatic Sciences 66.9, pp. 1522-1531.

Etheridge, S. M. and C. S. Roesler (2004). "Temporal variations in phytoplankton, particulates, and colored dissolved organic material based on optical properties during a Long Island brown tide compared to an adjacent embayment”. In: Harmful Algae 3.4, pp. 331-342. 
Floge, S. A. and M. L. Wells (2007). "Variation in colloidal chromophoric dissolved organic matter in the Damariscotta Estuary, Maine”. In: Limnology and Oceanography 52.1, pp. 32-45.

Foreman, C. and J. Covert (2003). "Linkages between Dissolved Organic Matter Composition and Bacterial Community Structure". In: Aquatic ecosystems : interactivity of dissolved organic matter. Elsevier. Chap. 14, pp. 343-362.

Gallegos, C. L. (2005). "Optical water quality of a blackwater river estuary: the Lower St. Johns River, Florida, USA”. In: Estuarine, Coastal and Shelf Science 63.1-2, pp. 57-72.

Guo, L. and R.W. Macdonald (2006). "Source and transport of terrigenous organic matter in the upper Yukon River: Evidence from isotope ( $\delta 13 \mathrm{C}, \Delta 14 \mathrm{C}$, and $\delta 15 \mathrm{~N}$ ) composition of dissolved, colloidal, and particulate phases”. In: Global Biogeochemical Cycles 20.2, n/a-n/a. Helms, J. R., A. Stubbins, J. D. Ritchie, E. C. Minor, D. J. Kieber, and K. Mopper (2008). "Absorption spectral slopes and slope ratios as indicators of molecular weight, source, and photobleaching of chromophoric dissolved organic matter". In: Limnology and Oceanography 53.3, pp. 955-969.

Horowitz, A. J., K. R. Lum, J. R. Garbarino, G. E. M. Hall, C. Lemieux, and C. R. Demas (1996). "The effect of membrane filtration on dissolved trace element concentrations". In: Water, Air, \& Soil Pollution 90.1-2, pp. 281-294.

Jerlov, N. (1968). Optical oceanography. New York: Elsevier Publishing Company, p. 194.

Jørgensen, L., S. Markager, and M. Maar (2014). "On the importance of quantifying bioavailable nitrogen instead of total nitrogen”. In: Biogeochemistry 117.2-3, pp. 455-472.

Kirk, J. T. O. (1994). Light and photosynthesis in aquatic ecosystems. 2nd. Cambridge [England] ; New York: Cambridge University Press, xvi, 509 p.

Knudsen-Leebeck, H. (2016). "The role of dissolved organic matter in the biogeochemical cycling of nutrients in coastal waters." Doctoral dissertation. Aarhus University, p. 163.

Kritzberg, E. S., S. Langenheder, and E. S. Lindström (2006). "Influence of dissolved organic matter source on lake bacterioplankton structure and function - implications for seasonal dynamics of community composition”. English. In: FEMS Microbiology Ecology 56.3, pp. 406-417.

Lambert, T., F. Darchambeau, S. Bouillon, B. Alhou, J.-D. Mbega, C. R. Teodoru, F. C. Nyoni, P. Massicotte, and A. V. Borges (2015). "Landscape Control on the Spatial and Temporal Variability of Chromophoric Dissolved Organic Matter and Dissolved Organic Carbon in Large African Rivers". In: Ecosystems 18.7, pp. 1224-1239.

Lapierre, J.-F. and J.-J. Frenette (2009). "Effects of macrophytes and terrestrial inputs on fluorescent dissolved organic matter in a large river system”. English. In: Aquatic Sciences 71.1, pp. 15-24.

Legendre, P. (2014). lmodel2: Model II Regression.

Mannino, A. and H. Harvey (2002). "Biochemical Composition of Dissolved Organic Matter Released During Experimental Diatom Blooms". In: NASA report. 
Markager, S., C. A. Stedmon, and M. Søndergaard (2011). "Seasonal dynamics and conservative mixing of dissolved organic matter in the temperate eutrophic estuary Horsens Fjord”. English. In: Estuarine, Coastal and Shelf Science 92.3, pp. 376-388.

Massicotte, P., E. Asmala, C. Stedmon, and S. Markager (2017). "Global distribution of dissolved organic matter along the aquatic continuum: Across rivers, lakes and oceans". In: Science of The Total Environment 609.C, pp. 180-191.

Massicotte, P. and S. Markager (2016). "Using a Gaussian decomposition approach to model absorption spectra of chromophoric dissolved organic matter". In: Marine Chemistry 180, pp. 24-32. Mladenov, N., R. Sommaruga, R. Morales-Baquero, I. Laurion, L. Camarero, M. Diéguez, A. Camacho, A. Delgado, O. Torres, Z. Chen, M. Felip, and I. Reche (2011). "Dust inputs and bacteria influence dissolved organic matter in clear alpine lakes". In: Nature Communications 2.May, p. 405. Morel, F. and P. Gschwend (1987). "The role of colloids in the partitioning of solutes in natural water”. In: Aquatic Surface Chemistry. Ed. by W. Stumm. Wiley. New York, pp. 405-422. Morrison, M. A. and G. Benoit (2001). "Filtration Artifacts Caused by Overloading Membrane Filters”. In: Environmental Science \& Technology 35.18, pp. 3774-3779.

Nayar, S. and L. Chou (2003). "Relative efficiencies of different filters in retaining phytoplankton for pigment and productivity studies". In: Estuarine, Coastal and Shelf Science 58.2, pp. 241-248.

Nimptsch, J., S.Woelfl, B. Kronvang, R. Giesecke, H. E. González, L. Caputo, J. Gelbrecht, W. von Tuempling, and D. Graeber (2014). "Does filter type and pore size influence spectroscopic analysis of freshwater chromophoric DOM composition?" In: Limnologica - Ecology and Management of Inland Waters 48, pp. 57-64.

Søndergaard, M., P. J. 1. B. Williams, G. Cauwet, B. Riemann, C. Robinson, S. Terzic, E. M. S. Woodward, and J. Worm (2000). "Net accumulation and flux of dissolved organic carbon and dissolved organic nitrogen in marine plankton communities". In: Limnology and Oceanography 45.5, pp. 1097-1111.

Stedmon, C. A. and S. Markager (2001). "The optics of chromophoric dissolved organic matter $(\mathrm{CDOM})$ in the Greenland Sea: An algorithm for differentiation between marine and terrestrially derived organic matter". English. In: Limnology and Oceanography 46.8, pp. 2087-2093.

Stedmon, C., R. Amon, A. Rinehart, and S. Walker (2011). "The supply and characteristics of colored dissolved organic matter (CDOM) in the Arctic Ocean: Pan Arctic trends and differences". In: Marine Chemistry 124.1-4, pp. 108-118.

Stedmon, C. A., S. Markager, M. Søndergaard, T. Vang, A. Laubel, N. H. Borch, and A. Windelin (2006). "Dissolved organic matter (DOM) export to a temperate estuary: seasonal variations and implications of land use". English. In: Estuaries and Coasts 29.3, pp. 388-400. 
Stedmon, C. A. and N. B. Nelson (2015). “The Optical Properties of DOM in the Ocean”. In: Biogeochemistry of Marine Dissolved Organic Matter. Ed. by D. A. Hansell and C. A. Carlson. Academic P. Burlington: Elsevier. Chap. 10, pp. 481-508.

Stramski, D. and S. B. Woźniak (2005). "On the role of colloidal particles in light scattering in the ocean". In: Limnology and Oceanography 50.5, pp. 1581-1591.

Sundh, I. (1992). "Biochemical composition of dissolved organic carbon derived from phytoplankton and used by heterotrophic bacteria." In: Applied and environmental microbiology 58.9, pp. 2938-47. Watanabe, S., I. Laurion, S. Markager, and W. F. Vincent (2015). "Abiotic control of underwater light in a drinking water reservoir: Photon budget analysis and implications for water quality monitoring". In: Water Resources Research 51.8, pp. 6290-6310.

Wells, M. L. and E. D. Goldberg (1993). “Colloid aggregation in seawater”. In: Marine Chemistry 41.4, pp. 353-358. 


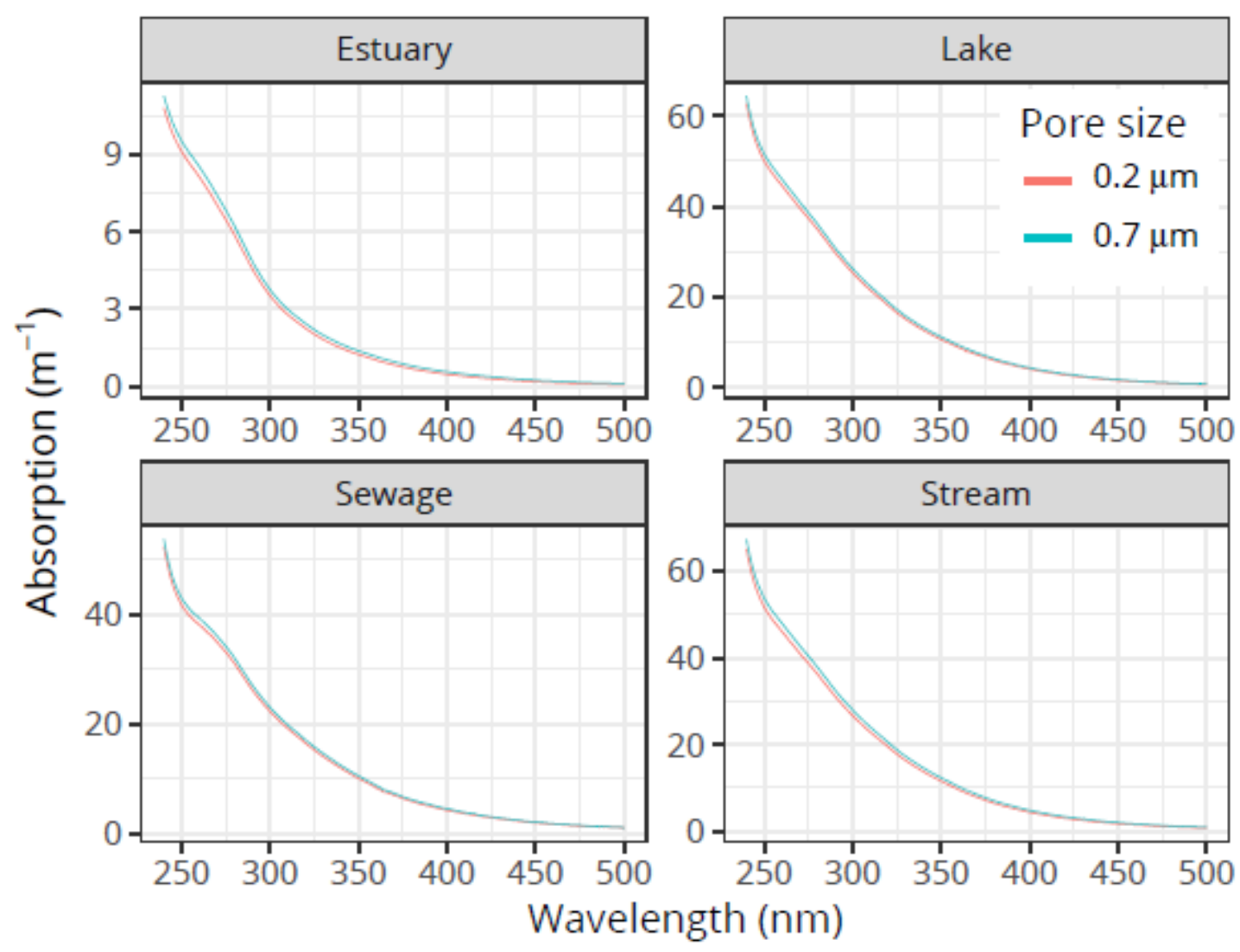

Figure 1: Absorption spectra averaged by ecosystems between 240 and 500 $\mathrm{nm}$. Note the different ranges spanned on the $\mathrm{Y}$ axis in the different panels. 


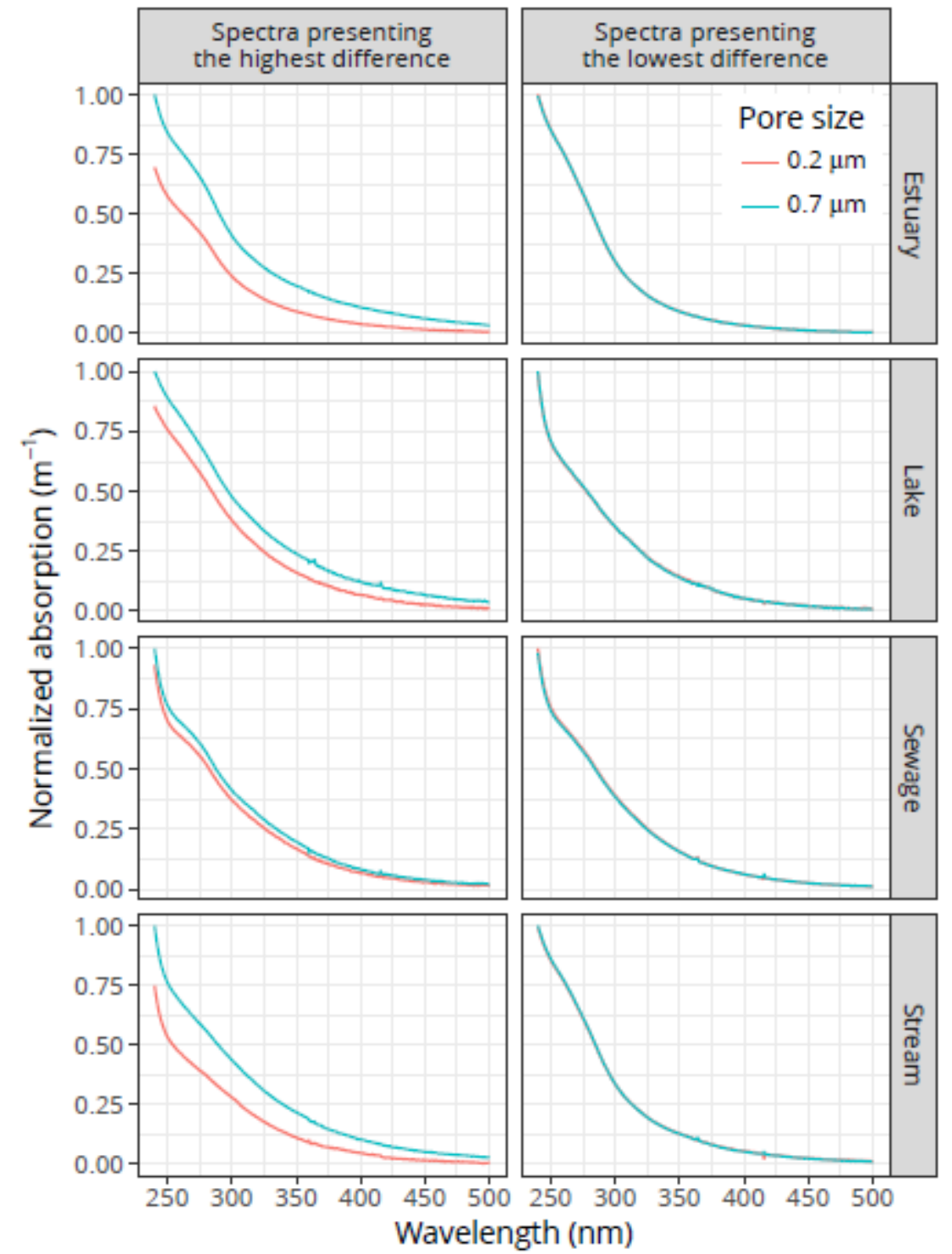

Figure 2: Absorption spectra presenting the highest (left column) and lowest (right column) difference for each ecosystem. Differences between paired spectra were calculated by subtracting the areas under curve (integral) of the 0.2 and $0.7 \mu \mathrm{m}$ spectra. Spectra have been normalized to the maximum absorption value of its paired $0.7 \mu \mathrm{m}$ spectra to better highlight differences between both filter pore sizes. 

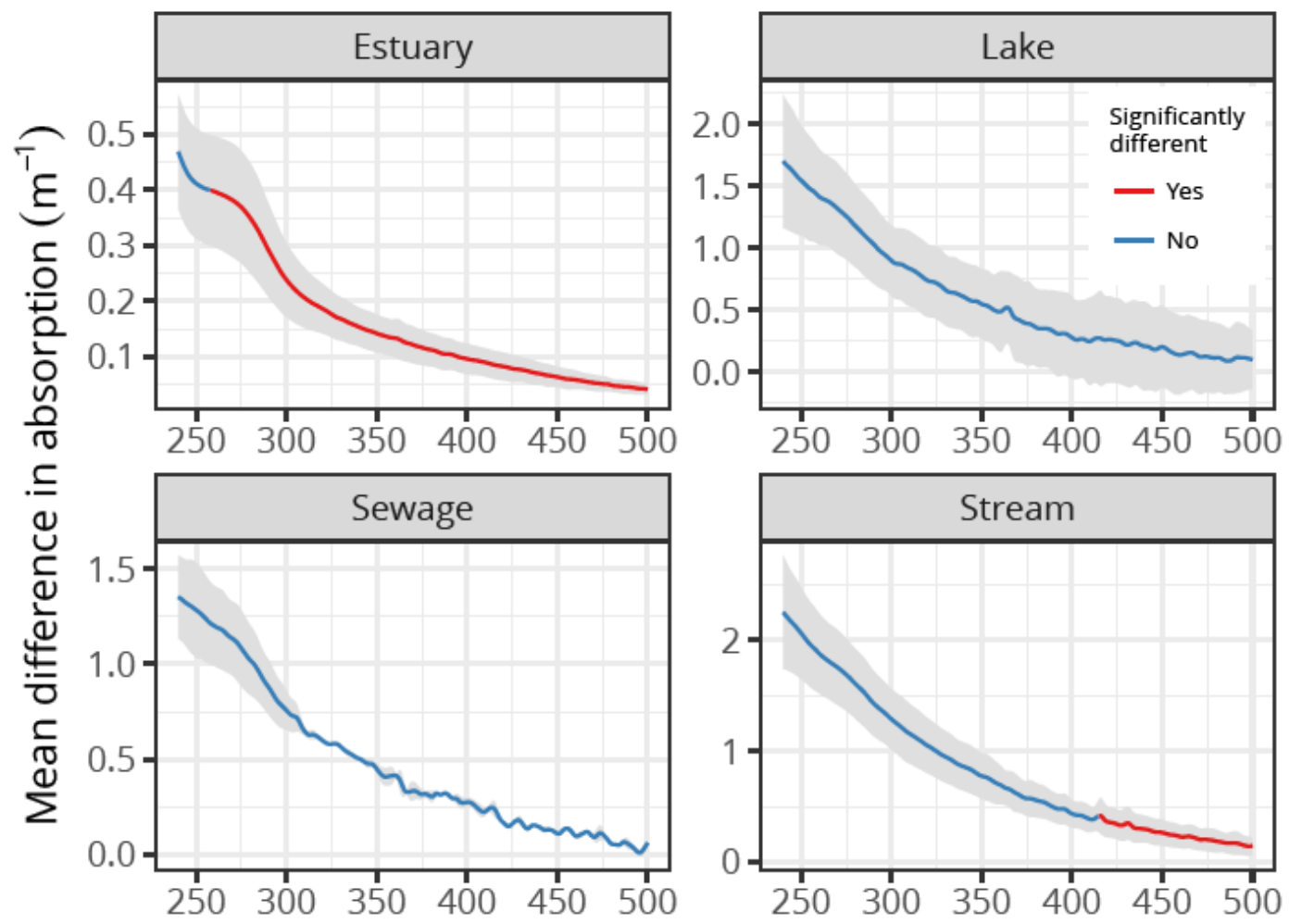

Wavelength $(\mathrm{nm})$

Figure 3: Colloidal absorption spectra: the mean difference in absorption at each wavelength for the four ecosystems studied $\left[a_{\mathrm{CDOM}}^{0.7 \mu m}(\lambda)-a_{\mathrm{CDOM}}^{0.2 \mu m}(\lambda)\right]$. Red solid lines indicate that the absorption measured on $0.7 \mu \mathrm{m}$ filtrate was significantly higher than that measured on $0.2 \mu \mathrm{m}$ based on an ANOVA analysis. Shaded areas represent the standard deviation around the calculated mean. 
A
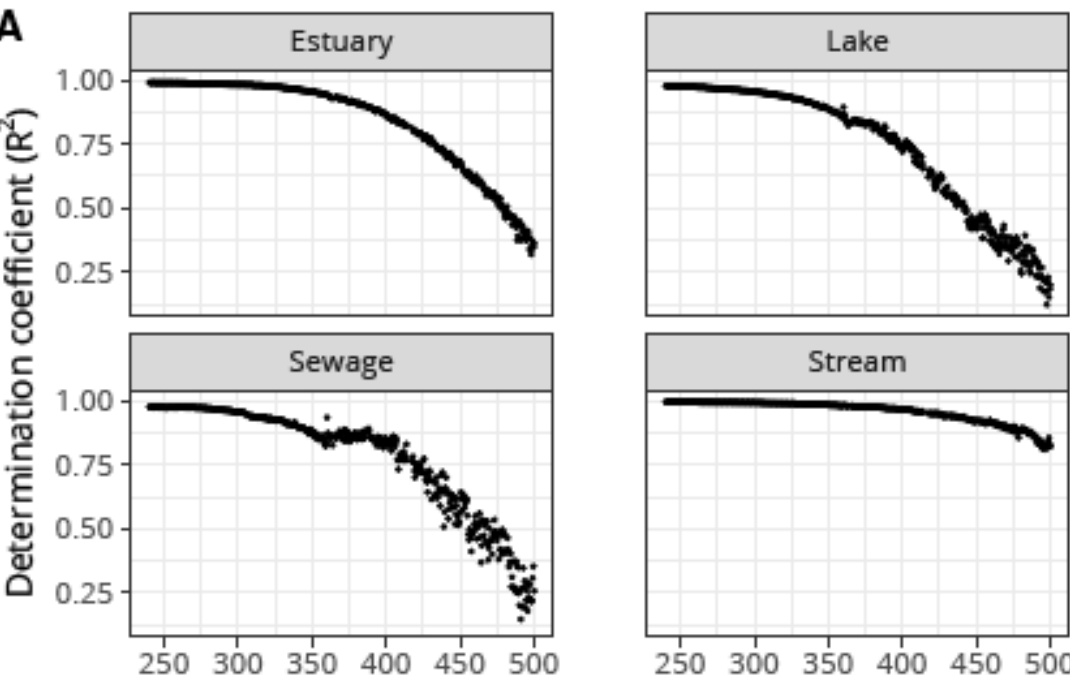

Wavelength $(\mathrm{nm})$

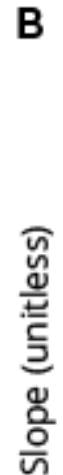
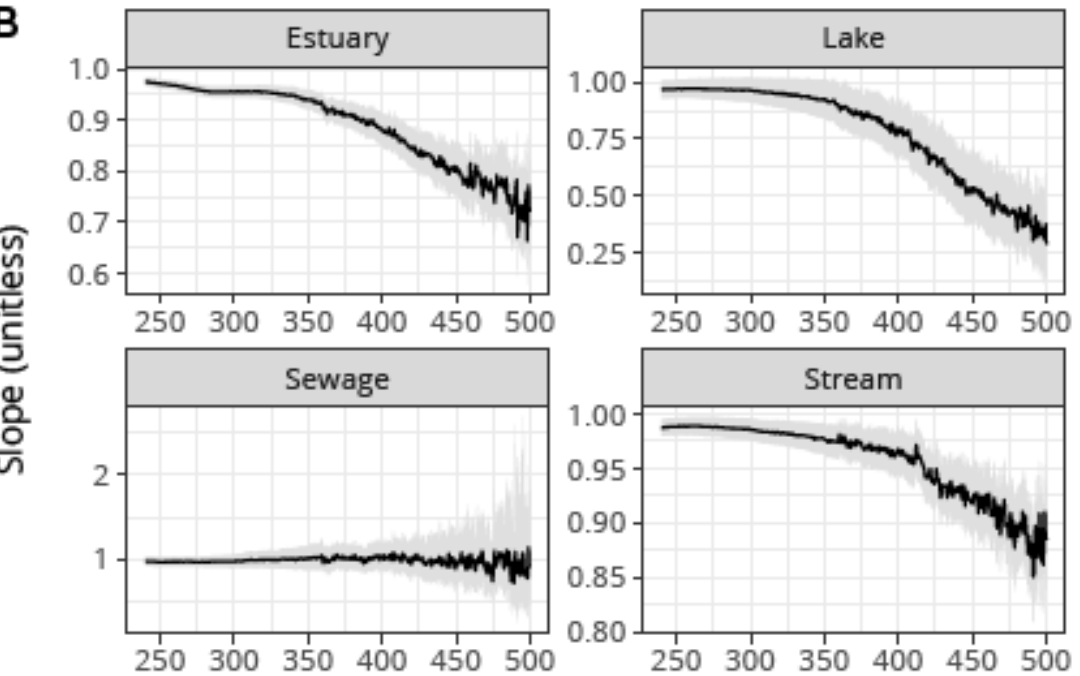

Wavelength (nm)

Figure 4: $(A)$ Determination coefficients $\left(R^{2}\right)$ of the orthogonal regression between absorption measured on 0.2 and $0.7 \mu \mathrm{m}$ at different wavelengths $(\mathrm{n}=561)$. (B) Slopes of the orthogonal regressions at different wavelengths. Shaded areas correspond to the $95 \%$ con1dence interval of the estimated parameters. Each orthogonal regression model (i.e. each point in the graph) is based on $471,62,33$ and 301 observations for estuary, lake, sewage and stream ecosystems. 

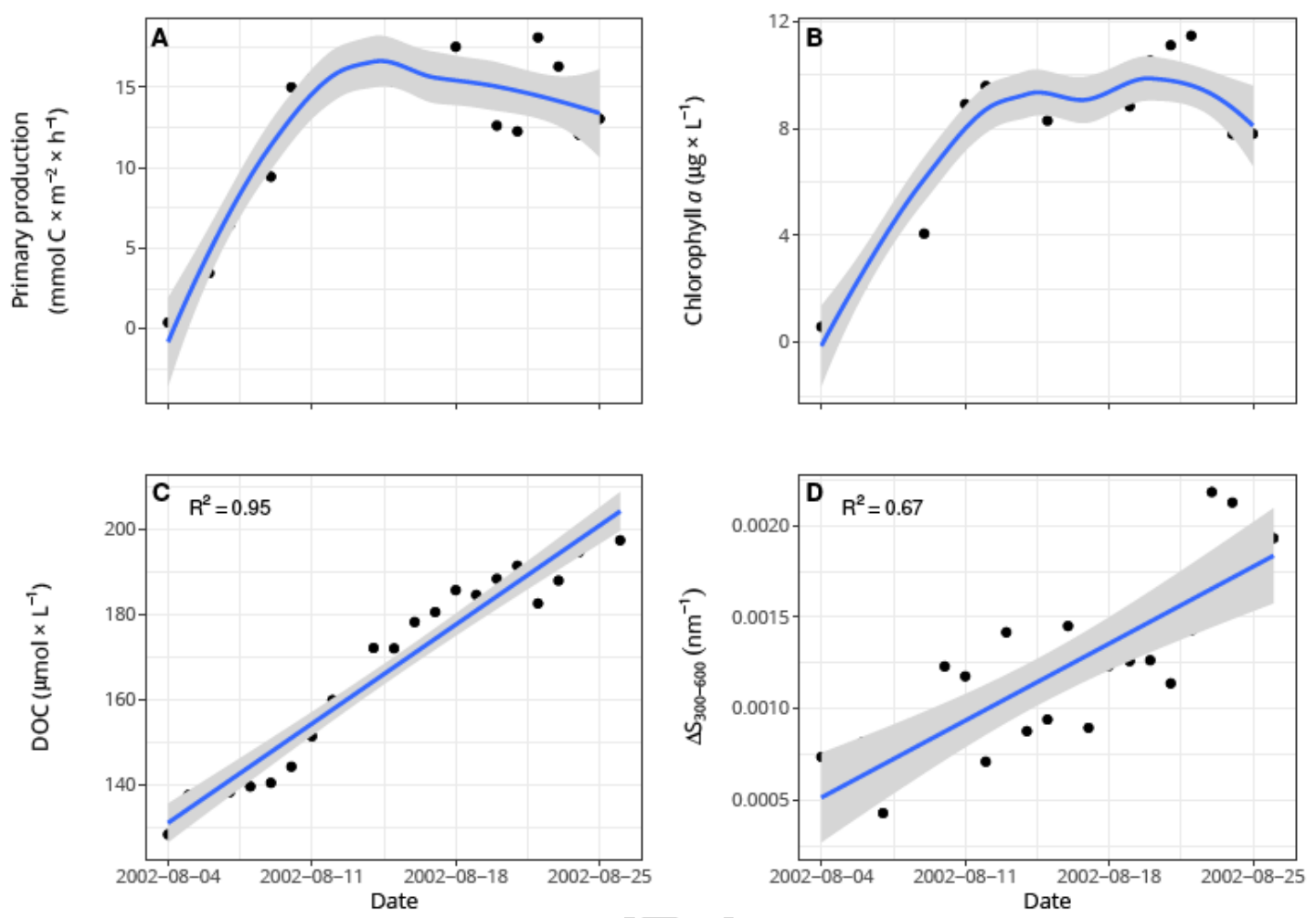

Figure 5: Averaged (A) primary production, (B) chlorophyll a, (C) dissolved organic carbon (DOC) and (D) $\Delta S_{300-600}$ over the time during the Bergen's experiment (see also supplementary Fig. 3,

$\left.\Delta S_{300-600}=S_{300-600}^{0.7 \mu m}\right)$. The smoothed solid blue lines represent 1 tted loesses whereas the straight lines represent the 1 tted linear models. The shaded areas correspond to the $95 \%$ con 1 dence intervals. 

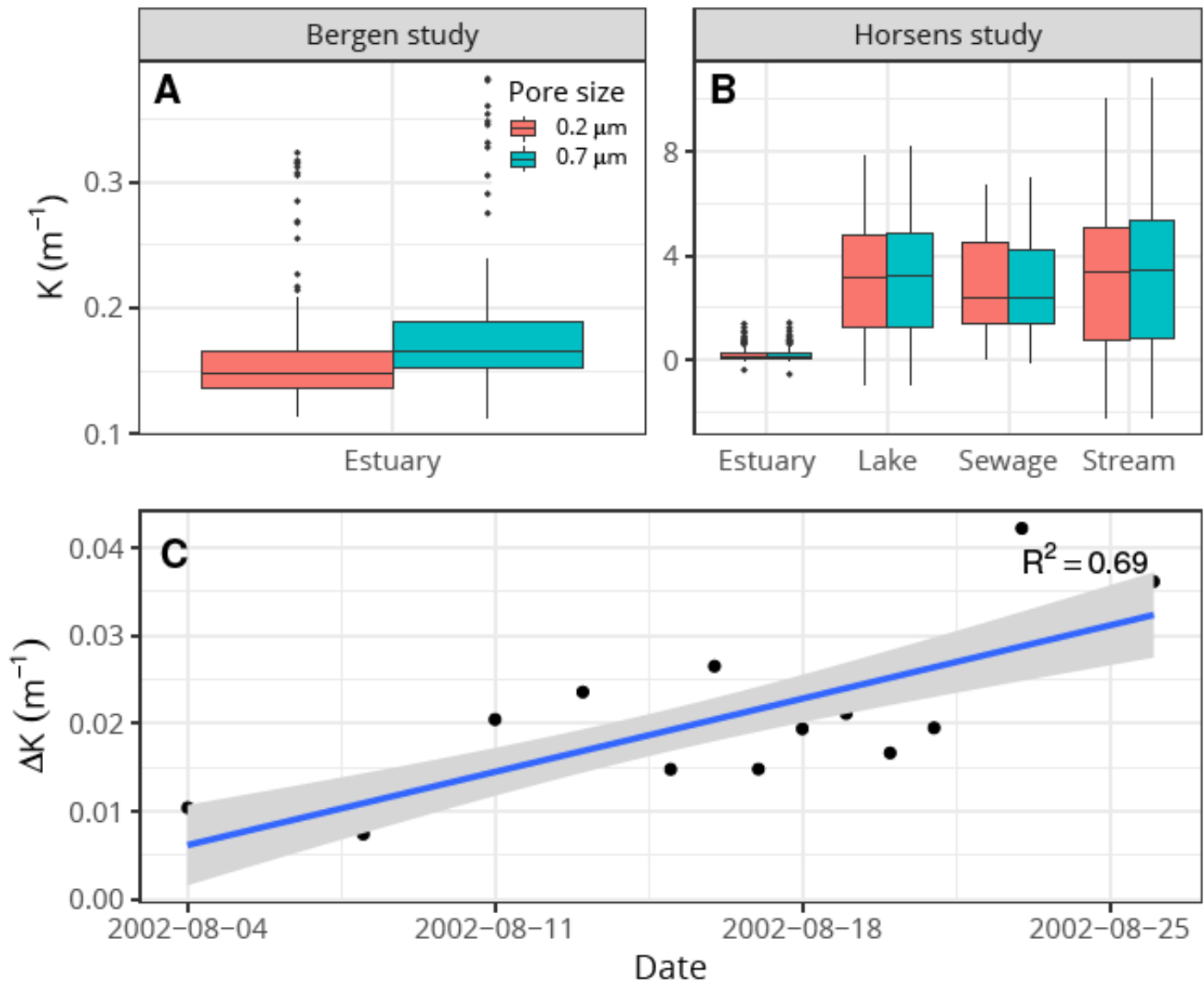

Figure 6: Boxplots comparing $\mathrm{K}$ parameter (equation 2) between (A) Bergen and (B) Horsen datasets for each ecosystem. Significant difference between $\mathrm{K}$ estimated from both 1 lter pore size was found in the Bergen data using ANOVA test $\left(\mathrm{F}_{(1,496)}=43: 61, p<0: 0001\right)$. (C) Variation in DK during the mesocosm experiment $\left(\Delta K=K_{0.7 \mu m}-K_{0.2 \mu m}\right)$. Note that the $\mathrm{K}$ parameter has been calculated between 220 and $700 \mathrm{~nm}$. 


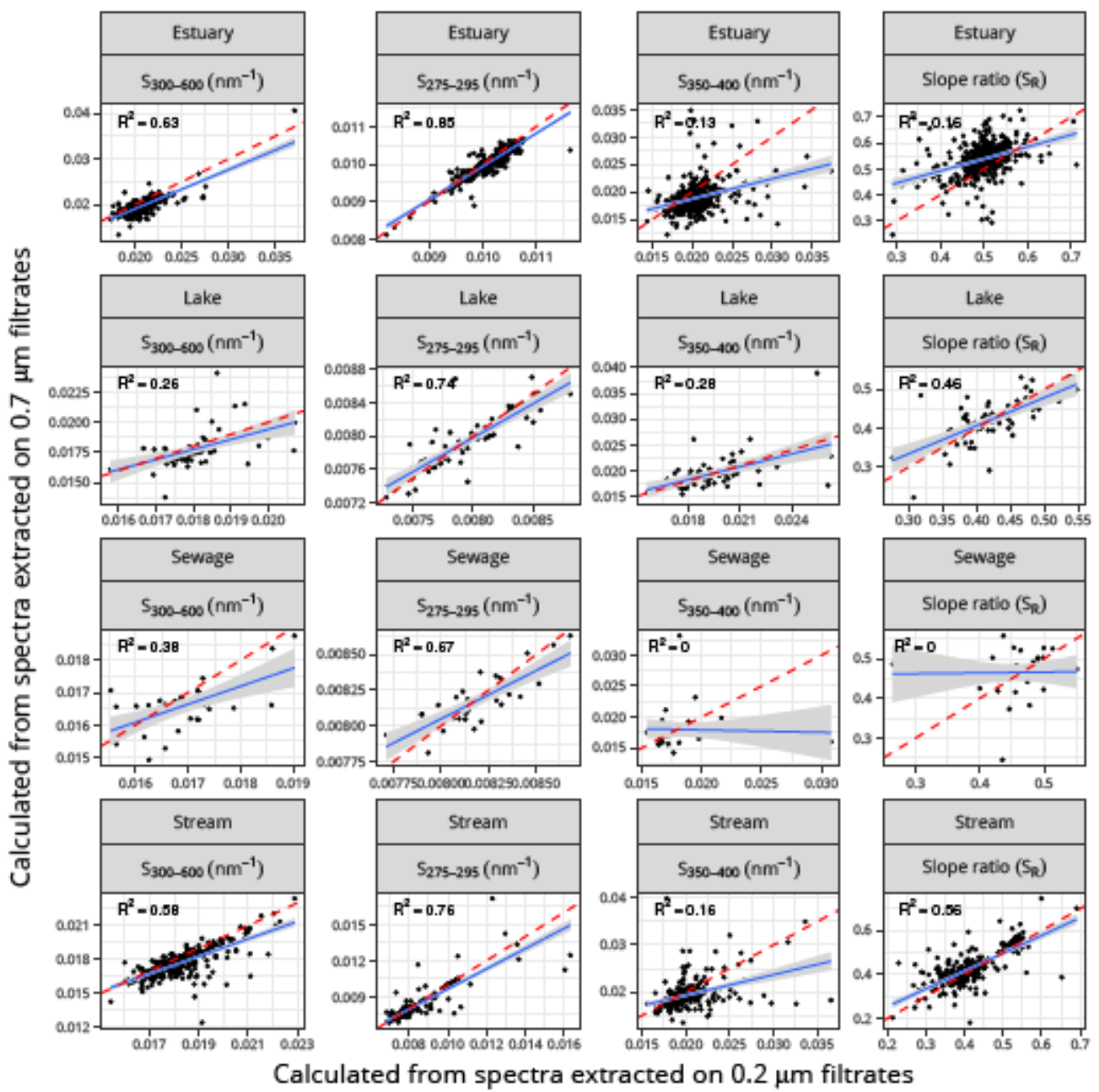

Figure 7: Scatterplots showing the relationships between metrics calculated on spectra measured on 0.2 and $0.7 \mu \mathrm{m}$ filters. The dashed red lines correspond to the $1: 1$ lines whereas the blue lines are the regression models. The shaded areas correspond to the $95 \%$ con 1 dence intervals. 


\section{Highlights}

1. 867 paired absorption spectra to study the effect of filter type on CDOM measures.

2. Fine particles $(0.2-0.7 \mu \mathrm{m})$ influence considerably the spectral signature of CDOM.

3. Phytoplankton-derived DOM increased measured absorption in productive environments.

4. Combining and comparing $\underline{\underline{\mathrm{CDOM}}}$ measured on 0.2 and $0.7 \mu \mathrm{m}$ should be done with care. 